\title{
Radiation retinopathy in a case of acute lymphocytic leukaemia
}

\author{
Subhakar Reddy (ㄱ , Komal Agarwal, Hitesh Agarwal, Mudit Tyagi
}

Smt Kanuri Santhamma Center for Vitreoretinal Diseases, LV Prasad Eye Institute, Hyderabad, India

\section{Correspondence to Dr Mudit Tyagi; drmudittyagi@gmail.com}

Accepted 9 August 2020

Check for updates

(c) BMJ Publishing Group Limited 2020. No commercial re-use. See rights and permissions. Published by BMJ.

To cite: Reddy S, Agarwal K, Agarwal $\mathrm{H}$, et al. BMJ Case Rep 2020;13:e237291 doi:10.1136/bcr-2020237291

\section{DESCRIPTION}

A 37-year-old man presented to us with diminution of vision in his both eyes since 1 month. He was a known case of acute lymphocytic leukaemia since 1 year and had received external beam radiotherapy of $24 \mathrm{~Gy}$ in 15 fractions of $1.6 \mathrm{~Gy}$ daily over 3 weeks for central nervous system spread in the past. He was currently under remission with maintenance dose of 6-mercaptopurine $125 \mathrm{mg} 3$ weeks a month and methotrexate $25 \mathrm{mg}$ once weekly. On examination, his best corrected visual acuity was 20/400 in the right eye and 20/125 in the left eye. Anterior segment examination was essentially normal in both eyes and there was no evidence of any rubeosis iridis. Intraocular pressure in the right and left eye was 14 and $12 \mathrm{~mm} \mathrm{Hg}$, respectively. Fundus examination of both eyes (figure $1 \mathrm{~A}$ and $\mathrm{B}$ ) showed cotton-wool spots, retinal haemorrhages, venous beading, microaneurysms and retinal pigment epithelial atrophy at macula. Fundus fluorescein angiography of both eyes (figure $1 \mathrm{C}$ and $\mathrm{D}$ ) revealed multiple microaneurysms, macular ischaemia and extensive capillary non-perfusion areas. An optical coherence tomography of both eyes (figure $1 \mathrm{E}$ and $\mathrm{F}$ ) showed macular oedema. So, a diagnosis of both eyes radiation retinopathy (RR) was made and he was treated with intravitreal antiVascular endothelial growth factor (VEGF) injection (IVA) followed by panretinal photocoagulation (PRP) in both the eyes.

RR can occur after exposure to any radiation source including external beam and plaque brachytherapy. Occurrence of RR depends on fractionation, field design, type and rate of administration of radiation, and the incidence of retinopathy has been reported to increase steadily at doses greater than $45 \mathrm{~Gy} .{ }^{1}$ Fractionation of radiation dose is defined as division of total radiation dose into multiple smaller doses over a span of several days thereby reducing its toxic effects. Hyperfractionation has been associated with a decreased incidence of RR. ${ }^{2}$ Comorbidities such as diabetes, hypertension and simultaneous chemotherapy are also associated with an increased risk of RR. ${ }^{3}$ Though fractionation of radiation dose was done in our patient, concurrent chemotherapy might have increased the risk of RR in our case.

RR can present with microaneurysms, macular oedema, cotton-wool spots, retinal neovascularisation, vitreous haemorrhage, tractional retinal detachment and neovascular glaucoma. ${ }^{4}$ IVA injections and PRP remain mainstay of treatment in early proliferative stages, and surgical intervention may be warranted in advanced stages.

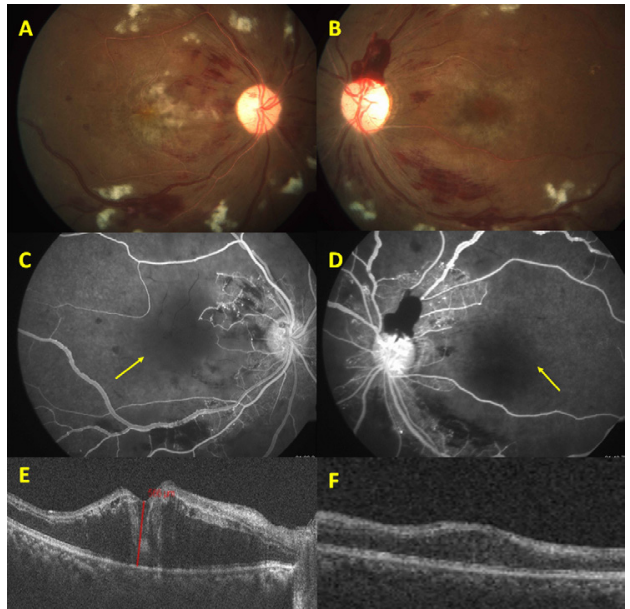

Figure $1(A, B)$ Fundus photograph of right and left eye, respectively, showing multiple flame shaped, intraretinal haemorrhages, cotton-wool spots, microaneurysms, sclerosis of arteries, beading of venules in both the eyes and preretinal haemorrhage superior to disc in the left eye. $(C, D)$ FFA of right and left eye, respectively, showing blocked fluorescence due to haemorrhages, extensive capillary non-perfusion areas, microaneurysms and enlarged foveal avascular zone (yellow arrow). ( $E, F)$ OCT of right and left eye, respectively, showing macular oedema. FFA, fundus fluorescein angiography; OCT, optical coherence tomography.

RR has been known to occur as early as 5 months after receiving radiation and has also been reported to occur many years later. ${ }^{56}$ Therefore, all patients subjected to a plaque brachytherapy for intraocular tumours or local external beam radiotherapy require regular ophthalmic evaluations, and a high index of suspicion for RR with regular follow-ups are essential in these patients. Controlling systemic comorbidities also plays a crucial role in patients receiving radiotherapy.

Contributors SR contributed to manuscript writing, data collection, editing, critical review of manuscript. KA and HA contributed to manuscript editing, critical review of manuscript. MT contributed to manuscript Editing, critical review of manuscript and finalising manuscript.

Funding The authors have not declared a specific grant for this research from any funding agency in the public, commercial or not-for-profit sectors.

Competing interests None declared.

Patient consent for publication Obtained.

Provenance and peer review Not commissioned; externally peer reviewed.

ORCID iD

Subhakar Reddy http://orcid.org/0000-0001-5683-7334 


\section{Learning points}

- Diabetics, hypertensives and people on concurrent chemotherapy are more predisposed to develop radiation retinopathy $(\mathrm{RR})$.

- Occurrence of RR depends on fractionation, field design, type and rate of administration of radiation, and hyperfractionation can decrease incidence of RR.

- Stringent screening criteria are essential for all patients receiving radiotherapy to look for any early signs of $R R$ and to limit subsequent vision loss.

\section{REFERENCES}

1 Parsons JT, Bova FJ, Fitzgerald CR, et al. Radiation retinopathy after externalbeam irradiation: analysis of Time-dose factors. Int I Radiat Oncol Biol Phys 1994;30:765-73.

2 Monroe AT, Bhandare N, Morris CG, et al. Preventing radiation retinopathy with hyperfractionation. Int J Radiat Oncol Biol Phys 2005;61:856-64.

3 Durkin SR, Roos D, Higgs B, et al. Ophthalmic and adnexal complications of radiotherapy. Acta Ophthalmol Scand 2007;85:240-50.

4 Zamber RW, Kinyoun JL. Radiation retinopathy. West J Med. 1992 Nov; 157(5):530-3. Review. Erratum in: West J Med 1993;158:201.

5 Char DH, Lonn LI, Margolis LW. Complications of cobalt plaque therapy of choroidal malanomas. Am J Ophthalmol 1977;84:536-41.

6 Stallard HB. Radiotherapy for malignant melanoma of the choroid. Br J Ophthalmol 1966;50:147-55.

Copyright 2020 BMJ Publishing Group. All rights reserved. For permission to reuse any of this content visit https://www.bmj.com/company/products-services/rights-and-licensing/permissions/

BMJ Case Report Fellows may re-use this article for personal use and teaching without any further permission.

Become a Fellow of BMJ Case Reports today and you can:

- Submit as many cases as you like

- Enjoy fast sympathetic peer review and rapid publication of accepted articles

- Access all the published articles

- Re-use any of the published material for personal use and teaching without further permission

\section{Customer Service}

If you have any further queries about your subscription, please contact our customer services team on +44 (0) 2071111105 or via email at support@bmj.com.

Visit casereports.bmj.com for more articles like this and to become a Fellow 